\title{
The sizes of Flat Plate and Evacuated Tube Collectors with Heat Pipe area as a function of the share of solar system in the heat demand
}

\author{
Małgorzata Olek ${ }^{1}$, Piotr Olczak ${ }^{1, a}$ and Dominik Kryzia ${ }^{2}$ \\ ${ }^{1}$ Institute of Thermal Engineering and Air Protection, Faculty of Environmental Engineering, Cracow University of Technology, Warszawska \\ 24, 31-155 Cracow, Poland \\ ${ }^{2}$ Mineral and Energy Economy Research Institute, Polish Academy of Sciences, Wybickiego 7, 31-261 Cracow, Poland
}

\begin{abstract}
The popularity of solar collectors in Poland is still increasing. The correct location of the collectors and a relatively high density of solar radiation allow delivering heat even in spite of relatively low ambient temperature. Moreover, solar systems used for heating domestic heat water (DHW) in summer allow nearly complete elimination of conventional energy sources (e.g. gas, coal). That is why more and more house owners in Poland decide to install solar system installations. In Poland the most common types of solar collectors are flat plate collectors (FPC) and evacuated tube collectors with heat pipe (ETCHP); both were selected for the analysis. The heat demand related to the preparation of hot water, connected with the size of solar collectors' area, has been determined. The analysis includes FPC and ETCHP and heat demand of less than $10000 \mathrm{kWh} /$ year. Simulations were performed with the Matlab software and using data from a typical meteorological year (TMY). In addition, a 126-year period of measurements of insolation for Krakow has been taken into account. The HDKR model (Hay, Davis, Klucher, Reindl) was used for the calculation of solar radiation on the absorber surface. The monthly medium temperature of the absorber depends on the amount of solar system heat and on the heat demand. All the previously mentioned data were used to determine solar efficiency. Due to the fact that solar efficiency and solar system heat are connected, the calculations were made with the use of an iterative method. Additionally, the upper limit for monthly useful solar system heat is resulted from the heat demand and thus the authors prepared a model of statistical solar system heat deviations based on the Monte Carlo method. It has been found that an increase in the useful solar system heat in reference to the heat demand is associated with more than proportional increase in the sizes of the analyzed surfaces of solar collector types.
\end{abstract}

\section{Introduction}

Solar conditions in Poland, variable depending on time and place, are moderate when compared to other European countries. This is related to favorable conditions for obtaining solar energy in the spring and summer months (April - August) (about $7.5 \mathrm{kWh} / \mathrm{m}^{2} /$ day) and unfavorable in the autumn and winter (about $0.1 \mathrm{kWh} / \mathrm{m}^{2} /$ day) [1]. The highest annual insolation is in the eastern part of the Lublin province $\left(>1048 \mathrm{kWh} / \mathrm{m}^{2} /\right.$ year $)$. In central Poland it is in the range from 1022 to $1048 \mathrm{kWh} / \mathrm{m}^{2} /$ year, while for the rest of the country insolation do not exceed 1000 $\mathrm{kWh} / \mathrm{m}^{2} /$ year $[2,3]$. In spite of the diversified conditions the amount of objects with solar systems in Poland is constantly increasing. The total area of solar collectors installed in Poland at the end of 2004 and 2014 amounted to $99000 \mathrm{~m}^{2}$ and $1744000 \mathrm{~m}^{2}$, respectively [4, 5]. The only producers and consumers of the energy from solar systems are trade and services sector and households (Fig 1.).

One of the important parameters of the solar system, especially for owners of single-family homes, is the selection of the optimum size of the collector area. Outside the local weather conditions and the amount of heat needed for domestic hot water (DHW) or low-temperature central heating systems (floor or wall-mounted), the collector area can be associated with the demand for DHW and the type of heat source [7]. The increased interest in solar energy in Poland has resulted in a number of studies regarding the selection of collector area but these are mainly focused on flat plate collectors [8-12].

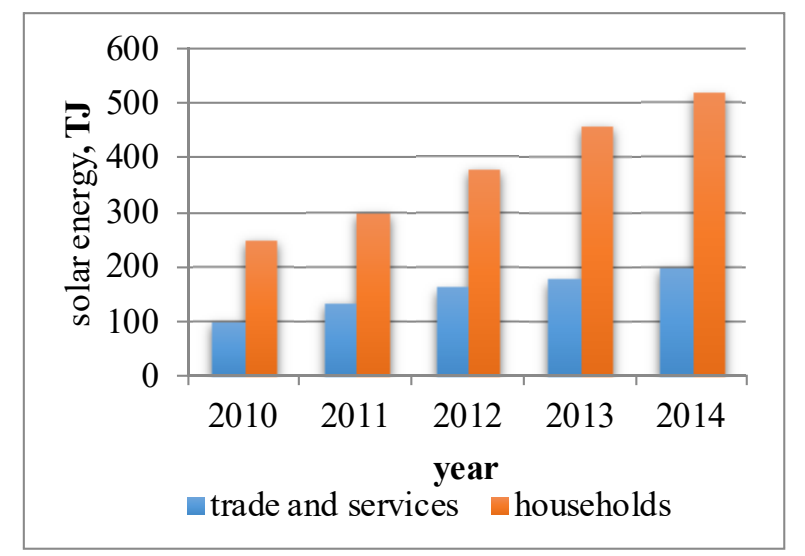

Figure 1. The amount of energy generated from solar radiation in Poland in the years 2010-2014 [6].

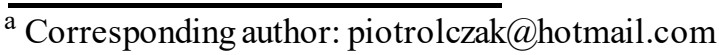


The gross area (GA), absorber area (AA) and aperture area (AAp) for the variable, dependent on the number of residents, heat demand for the preparation of DHW and the variable degree of meeting this demand by the solar system, have been determined in the paper. The analysis has been conducted for flat plate collectors (FPC) and evacuated tube collectors with heat pipe (ETCHP). The paper has resulted in nomograms allowing the owner of a single-family building, knowing the amount of heat needed for DHW, to choose the collector area depending on the degree of meeting the heat demand.

\section{Research object}

\subsection{Heat demand for domestic hot water}

A residential building located in Cracow inhabited by a maximum of 6 people was selected as the object of the analysis. The annual heat demand for $\operatorname{DHW}\left(\mathrm{Q}_{\mathrm{w}, \mathrm{a}}\right)$ was estimated from the relationship [13]:

$$
Q_{w, a}=\frac{\left(\mathrm{V}_{\mathrm{DHW}} \cdot n_{\mathrm{r}} \cdot \mathrm{C}_{\mathrm{W}} \cdot \rho_{\mathrm{W}} \cdot\left(\mathrm{T}_{\mathrm{w}}-\mathrm{T}_{\mathrm{O}}\right) \cdot 365\right.}{3600 \cdot \eta_{\mathrm{tot}}}
$$

where:

$\mathrm{V}_{\mathrm{DHW}}$ - average daily demand for DHW, $\mathrm{dm}^{3} /$ resident

$\mathrm{n}_{\mathrm{r}}$ - number of residents,

$\mathrm{c}_{\mathrm{w}}$ - specific heat of water, $\mathrm{kJ} /(\mathrm{kgK})$,

$\rho_{\mathrm{w}}$ - density of water, $\mathrm{kg} / \mathrm{dm}^{3}$,

$\mathrm{T}_{\mathrm{w}}$ - temperature of hot water, ${ }^{\circ} \mathrm{C}$,

$\mathrm{T}_{\mathrm{o}}$ - temperature of cold water, ${ }^{\circ} \mathrm{C}$,

$\eta_{\text {tot }}-$ domestic hot water system efficiency.

It was assumed that the differences in cold water inlet temperature correlate with seasonal fluctuations in demand for DHW and the perceived temperature of hot water. Under Cracow conditions, cold water temperature is in the range between 2 and $20^{\circ} \mathrm{C}$ [14]. The simulation assumed the cold water inlet temperature $\left(\mathrm{T}_{0}\right)$ and the tap water temperature $\left(\mathrm{T}_{\mathrm{w}}\right)$ at $10^{\circ} \mathrm{C}$ and $55^{\circ} \mathrm{C}$, respectively [15]. The assumed specific heat of water $\left(\mathrm{c}_{\mathrm{W}}\right)$ and density of water $\left(\rho_{\mathrm{W}}\right)$ were $4.18 \mathrm{~kJ} /(\mathrm{kg} \cdot \mathrm{K})$ and $1 \mathrm{~kg} / \mathrm{dm}^{3}$, respectively. Theoretical and actual daily DHW consumption is presented in Table 1. The analysis of the demand for DHW was performed for the range from 20 to $70 \mathrm{dm}^{3} /$ resident/day. The assumed efficiency of DHW system $\left(\eta_{\text {tot }}\right)$ was 0.69 .

Table 1. Daily water consumption per capita in residential buildings

\begin{tabular}{|l|c|}
\hline Building & DHW, $\mathrm{V}_{\text {DHW }}$ \\
\hline & $\mathrm{dm}^{3} /$ resident $/$ day \\
\hline Multi-family house [16] & $19.4-48$ \\
\hline Single-family house [17] & $37.5-39.3$ \\
\hline EN 15316:3:2007 standard & $36-66.7$ \\
\hline
\end{tabular}

An annual heat demand required $\left(\mathrm{Q}_{\mathrm{w}, \mathrm{a}}\right)$ for the preparation of DHW depending on the number of inhabitants and the daily demand for DHW is shown in Fig. 2.

Further analysis of the collector area was carried out for the heat demand for DHW in the range from 1000 to $10000 \mathrm{kWh} /$ year.

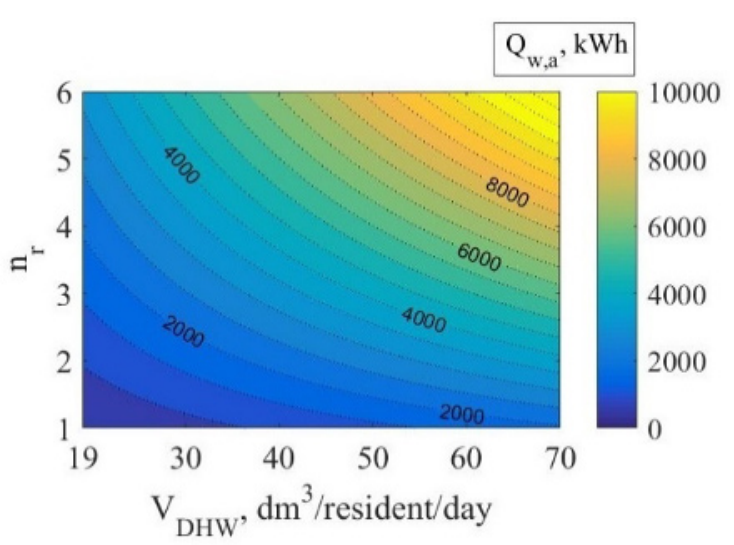

Figure 2. The annual heat demand for DHW as a function of the number of inhabitants and the average daily demand for DHW

\subsection{Collectors}

In Poland, flat plate collectors (74\%), followed by evacuated tube collectors (26\%), are the most popular types of solar systems [18]. Tube collectors can be divided into several subtypes: evacuated tube collectors with heat pipes or parabolic mirror collectors (CPC - Compound Parabolic Concentrators).

Flat plate collectors (FPC) are made of transparent protective cover, absorber, flow channels and insulation (mineral wool). The gross area of FPC depends on the surface of the absorber mounted in a rectangular metal housing (Fig. 3A). The aperture area of FPC depends on the way of mounting the glass protective panels and is usually smaller than the absorber area.

Evacuated tube collectors with heat pipes (ETCHP) usually consist of parallel rows of glass tubes. The outer tube has a protective function, while the inner tube is coated with an absorptive coating. Between tubes is formed a vacuum. The heat pipe is positioned coaxially to the glass tubes. It is filled with a liquid with a low boiling point. The heat between the absorber and the heat pipe is transmitted mainly by the heat exchange fin (Fig. 3B). A set of pipes is connected to the manifold tube where the heat exchange between the heat pipes and the solar fluid takes place. The manifold tube is not involved in the absorption of solar radiation. The gross area of ETCHP depends on the dimensions of the single outer tube $\left(\mathrm{d}_{\mathrm{o}}\right)$, the number of tubes, the distance between them $\left(\mathrm{d}_{\mathrm{bp}}\right)$ and the dimensions of the manifold tube. The distance between the tubes is optimized in order to minimize the risk of overlapping of the tubes and to maximize the absorber area relative to the gross area. The absorber area is calculated [19]:

$$
\mathrm{AA}=\mathrm{d}_{\mathrm{a}} \cdot \mathrm{L} \cdot \mathrm{p}(2)
$$

$\mathrm{AA}$ - absorber area, $\mathrm{m}^{2}$

$\mathrm{d}_{\mathrm{a}}-$ outer diameter of inner tube (Fig. 3B), m,

$\mathrm{L}$ - length of tube, $\mathrm{m}$,

$\mathrm{p}-$ numbers of pipes.

The aperture area for ETCHP is calculated as the product of the inner diameter of the outer tube, its length and numbers of pipes. 


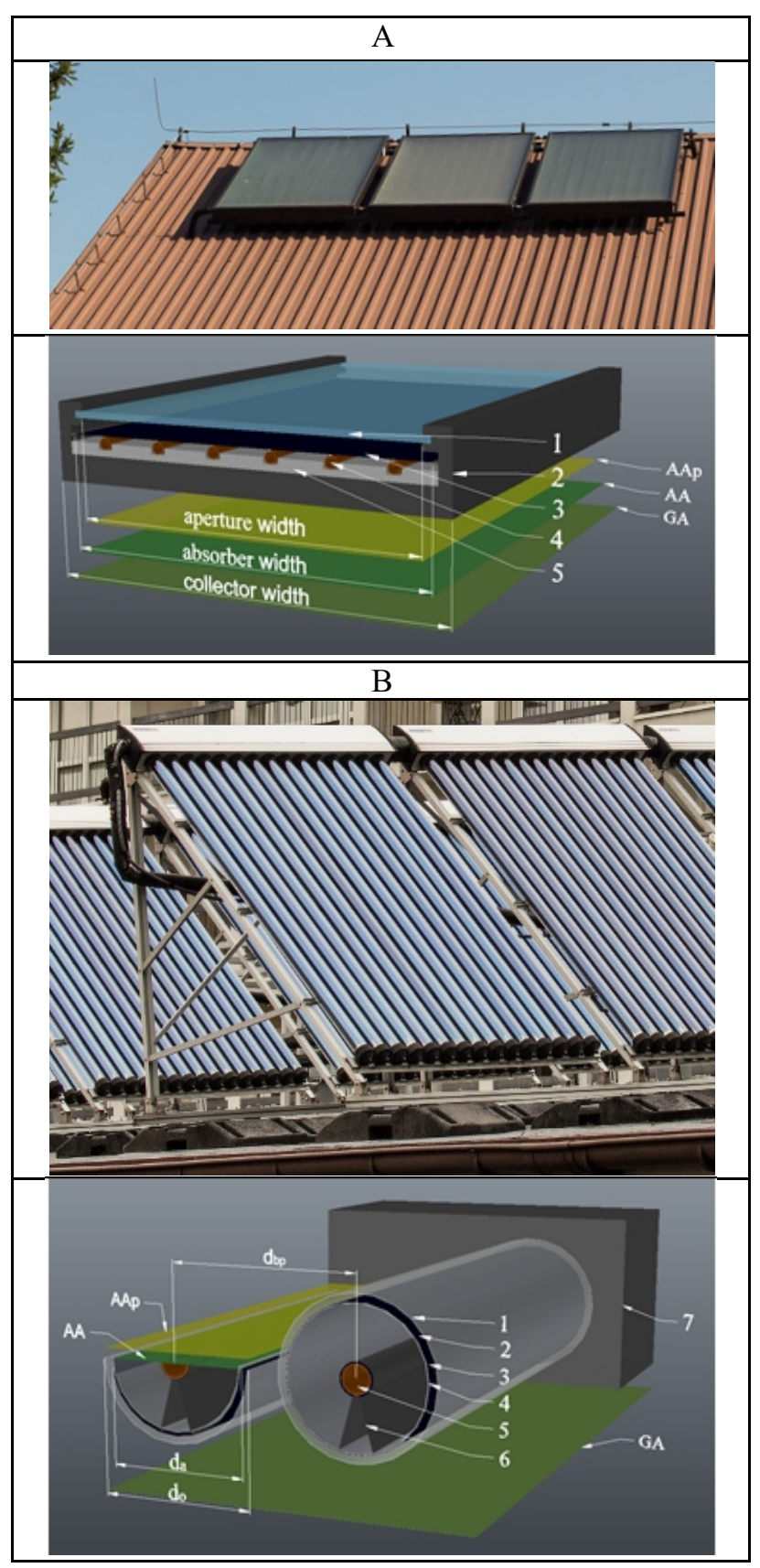

Figure 3. Solar collectors, GA-gross area, AAp - aperture area, AA - absorber area A) Flat plate collectors (1-transparent cover, 2- metal housing 3-absorber, 4 - flow channels, 5- isolation); B) Evacuated tube collectors (1- outer glass tube, 2- vacuum, 3absorber, 4 -inner glass tube, 5- heat pipe, 6- heat exchange fin, 7- manifold tube).

The main difference between FPC and ETCHP is their efficiency (Table 2). The advantage of ETCHP is associated with the properties of insulation layer of the vacuum. The thermal conductivity coefficient for this layer is in the range from 0.001 to $0.0025 \mathrm{~W} /(\mathrm{m} \cdot \mathrm{K})$. In the case of the insulating layer in FPC, that is the air between the absorber and the glass panel, it amounts to $0.026 \mathrm{~W} /(\mathrm{m} \cdot \mathrm{K})$ [20]. The linear heat loss coefficient $\left(\mathrm{a}_{1}\right)$ for FPC depends on the model of collector and can vary from 2.741 $\mathrm{W} /\left(\mathrm{m}^{2} \cdot \mathrm{K}\right)$ to $4.999 \mathrm{~W} /\left(\mathrm{m}^{2} \cdot \mathrm{K}\right)[21-30]$, while for the ETCHP is in the range from $0.749 \mathrm{~W} /\left(\mathrm{m}^{2} \cdot \mathrm{K}\right)$ to $1.771 \mathrm{~W} /\left(\mathrm{m}^{2} \cdot \mathrm{K}\right)[31,32]$. For a selected day of May 23 the potential ranges of solar yields for boundary coefficients $\left(\mathrm{a}_{1}\right)$ are presented in Fig. 4.

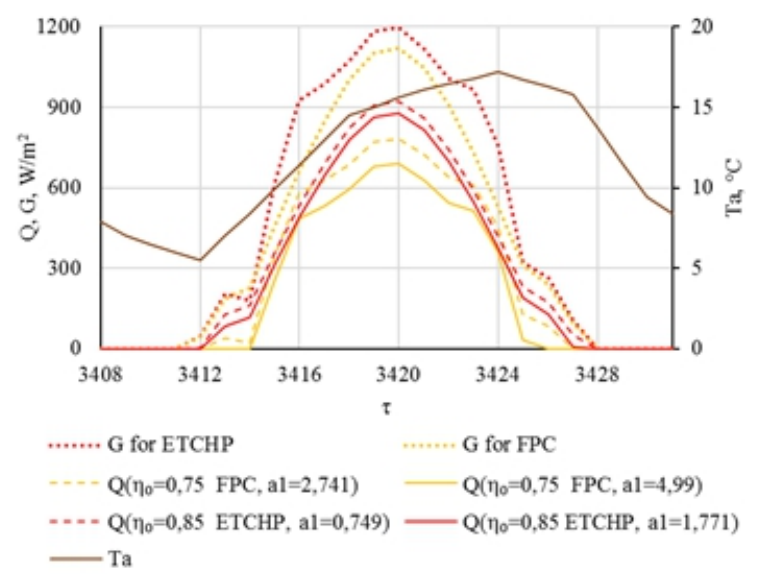

Figure 4. Comparison of the impact of the coefficient $a_{1}$ on the acquisition of solar energy for the analyzed collectors, $\mathrm{T}_{\mathrm{m}}=50^{\circ} \mathrm{C}$.

The second difference is the access to solar radiation, affected by the shape of the absorber [19] and favorable for ETCHP (Fig. 5).

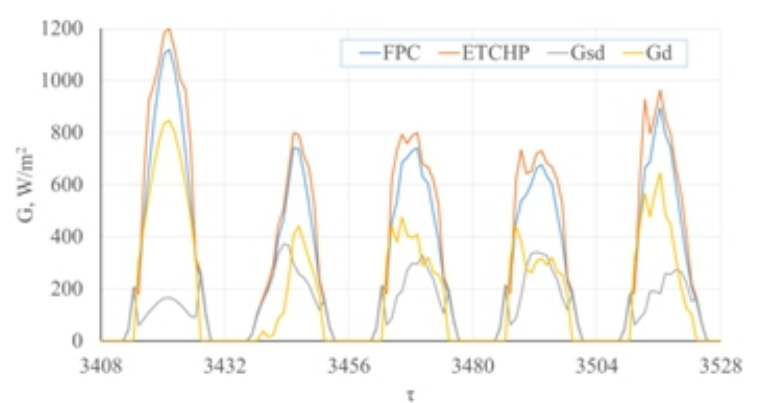

Figure 5. The intensity of solar radiation calculated on the surface of the FPC and ETCHP absorber for the selected days in a typical meteorological year and the available beam $\left(\mathrm{G}_{\mathrm{d}}\right)$ and diffuse radiation $\left(\mathrm{G}_{\mathrm{sd}}\right)$.

The paper assumed that the diameters of the analyzed vacuum tubes $\left(\mathrm{d}_{\mathrm{o}}\right)$ and absorber $\left(\mathrm{d}_{\mathrm{a}}\right)$ are $0.058 \mathrm{~m}$ and $0.0514 \mathrm{~m}$, tube length at $1.8 \mathrm{~m}$ and the distance between the axes of adjacent tubes $\left(\mathrm{d}_{\mathrm{bp}}\right)$ are $0.078 \mathrm{~m}$. The simulated optical efficiency $\left(\eta_{0}\right)$, linear $\left(a_{1}\right)$ and nonlinear $\left(a_{2}\right)$ heat loss coefficients for ETCHP correspond to the values typical for the Energosol collector (Table 1) tested in a large-scale installation $[33,34]$. In the case of FPC, the Watt 2020 collector technical data has been used [25].

Table 2. The parameters of FPC and ETCHP collectors and the surface conversion $[25,32,35]$.

\begin{tabular}{|l|l|l|l|}
\hline & Unit & FPC & ETCHP \\
\hline$\eta_{0}$ & - & 0.750 & 0.850 \\
\hline $\mathrm{a}_{1}$ & $\mathrm{~W} /\left(\mathrm{m}^{2} \cdot \mathrm{K}\right)$ & 3.517 & 1.771 \\
\hline $\mathrm{a}_{2}$ & $\mathrm{~W} /\left(\mathrm{m}^{2} \cdot \mathrm{K}^{2}\right)$ & 0.017 & 0.0192 \\
\hline $\mathrm{AA} / \mathrm{GA}$ & - & $1.88 / 2.04$ & $1.21 / 2.42$ \\
\hline $\mathrm{AAp} / \mathrm{GA}$ & - & $1.87 / 2.04$ & $1.4 / 2.42$ \\
\hline
\end{tabular}

It was assumed that the collectors are oriented towards the south (azimuth $0^{\circ}$ ) and are set at an angle $\beta=30^{\circ}$ 
to the ground level [10]. The collectors are located on the roof covered with a reflectance coefficient $\left(\mathrm{r}_{\mathrm{c}}\right)$ of 0.1 . For ground surface, the assumed reflectance coefficient $\left(\mathrm{w}_{\mathrm{o}}\right)$ was $0.2[36]$.

Olczak et al. experimentally indicated that, even in the case of oversized collectors, there are periods of adverse weather conditions in the months of May or June, requiring to support the solar system with conventional source of energy eg. boiler [37, 38]. Therefore, the study has adopted a variant with a solar system delivering max. $90 \%$ of the monthly heat demand. The possible excess heat has not been included in the balance of useful energy.

Calculations of the potential solar yields for the investment located in Cracow have been performed for $1 \mathrm{~m}^{2}$ of the absorber area. Assuming the demand and the conversions area factors (AA/GA and AAp/GA) for the particular type of solar collectors (Tab. 1), the total absorber area (AA), gross area (GA) and aperture area (AAp) have been estimated. In the case of FPC, the aperture and absorber areas weren't analyzed separately due to the fact that the difference between these surfaces is only about $0.6 \%$.

\section{Computational model of solar radiation}

The intensity of solar radiation for each hour of the reference year $(\tau)$ has been determined using the HDKR (Hay, Davis, Klucher, Reindl) radiation model [36, 39]. The aforementioned model takes into account the beam solar radiation $\left(\mathrm{G}_{\mathrm{d}}\right)$, diffuse circumsolar radiation $\left(\mathrm{G}_{\mathrm{dh}}\right)$, diffuse isotropic radiation $\left(\mathrm{G}_{\mathrm{di}}\right)$, diffuse horizontal radiation $\left(\mathrm{G}_{\mathrm{dlh}}\right)$ and diffuse reflected radiation $\left(\mathrm{G}_{\mathrm{dr}}\right)$ (Fig. $6)$ and its one of the most accurate models $[40,41]$. For each hour $(\tau)$ of the year and the variable tilt the collector surface to the ground level ( $\beta$ ), the HDKR model can be expressed with the equation (3):

$$
\begin{gathered}
G(\tau, \beta)=G_{d}(\tau, \beta)+G_{d h}(\tau, \beta)+G_{d i}(\tau, \beta)+ \\
G_{d l h}(\tau, \beta)+G_{d r}(\tau, \beta)
\end{gathered}
$$

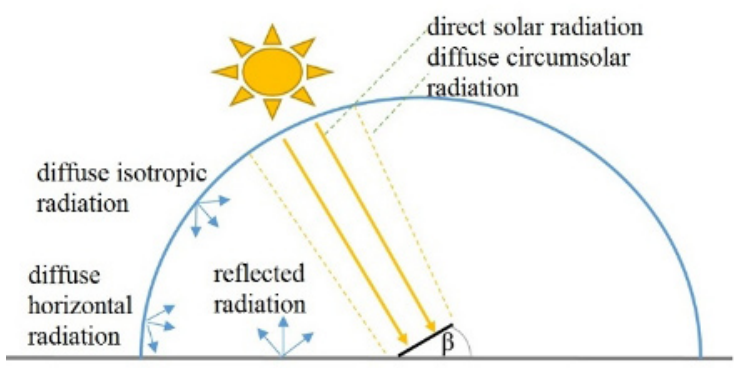

Figure 6. The scheme of radiation on the collector surface [39, 36].

The analysis of the available solar radiation has been performed for hourly data from the reference year for the Cracow-Balice weather station $\left(19.9167^{\circ} \mathrm{E}\right.$, $\left.50.0833^{\circ} \mathrm{N}\right)$. The data on the ambient temperature $\left(\mathrm{t}_{\mathrm{a}}\right)$, direct $\left(\mathrm{G}_{\mathrm{d}}\right)$ and the sum of diffuse solar radiation $\left(\mathrm{G}_{\mathrm{sd}}\right)$ on a horizontal surface $\left(\beta=0^{\circ}\right)$ have been used in the HDKR model [42].

When calculating the apparent movement of the sun, the latitude of Cracow has been taken into account. What is more, changes resulting from the difference between solar time for the meridian $19.9167^{\circ} \mathrm{E}$ and for the GMT time have also been included [42]. Due to the analysis of the average hourly data, the equation of time $\mathrm{E}$ has been omitted.

The angle of the collector to the ground level $\beta=30^{\circ}$ for Cracow adopted in the model results in the highest yields per year assuming good heat collection efficiency [10]. In addition, for the adopted angle, the diffuse horizontal radiation $[36,39]$ and reflected radiation $[36,39]$ have a limited share in the intensity of radiation incident on the absorber.

The available solar radiation incident on the absorber of the FPC directed south at an angle $\beta$ for each hour of referenceyear $(\tau)$ is calculated with the following formula:

$$
\begin{gathered}
G(\tau)=R_{b}(\tau) \cdot K_{\theta}(\tau) \cdot\left(G_{d}(\tau)+A i(\tau) \cdot G_{s d}(\tau)\right)+R_{d} . \\
K_{\theta d} \cdot\left(1-A_{i}(\tau)\right) \cdot\left(1+R_{j h}(\tau)\right)+w o \cdot R_{o} \cdot K_{\theta d} \cdot \\
\left(G_{d}(\tau)+G_{s d}(\tau)\right)
\end{gathered}
$$

where :

$\mathrm{G}$ - available intensity of solar radiation incident on absorber dependent on time (for the average year), $\mathrm{W} / \mathrm{m}^{2}$ $\mathrm{G}_{\mathrm{d}}$ - beam radiation on a horizontal surface, $\mathrm{W} / \mathrm{m}^{2}$ $\mathrm{G}_{s d}$ - diffuse radiation on a horizontal surface, $\mathrm{W} / \mathrm{m}^{2}$ $\mathrm{A}_{\mathrm{i}}$ - anisotropy index,

$\mathrm{R}_{\mathrm{b}}$ - geometric factor of beam radiation on tilted collector to that on a horizontal surface,

$\mathrm{R}_{\mathrm{d}}$ - geometric factor for diffuse radiation,

$\mathrm{R}_{\mathrm{jh}}$ - geometric factor for diffuse brightness horizontal radiation,

$\mathrm{R}_{0}$ - geometric factor for diffuse reflected radiation (reflected by surfaces in front of collector),

$\mathrm{W}_{\mathrm{o}}$ - reflection factor from ground,

$\mathrm{K}_{\theta}$ - incident angle modifier for beam radiation,

$\mathrm{K}_{\theta \mathrm{d}}$ - incident angle modifier for diffuse solar radiation.

The correction factor for diffuse horizontal radiation $\left(R_{d}\right)$ and diffuse radiation $\left(R_{0}\right)$ is dependent on angle of the collector to the ground level and for $\beta=30^{\circ}$ is 0.933 and 0.067 , respectively. The incident angle modifier $\mathrm{K}_{\theta}$ was determined using data for the Watt collector [25]-Fig. 7. For diffuse solar radiation, the $\mathrm{K}_{\theta \mathrm{d}}$ is assumed at 0.95 [43].

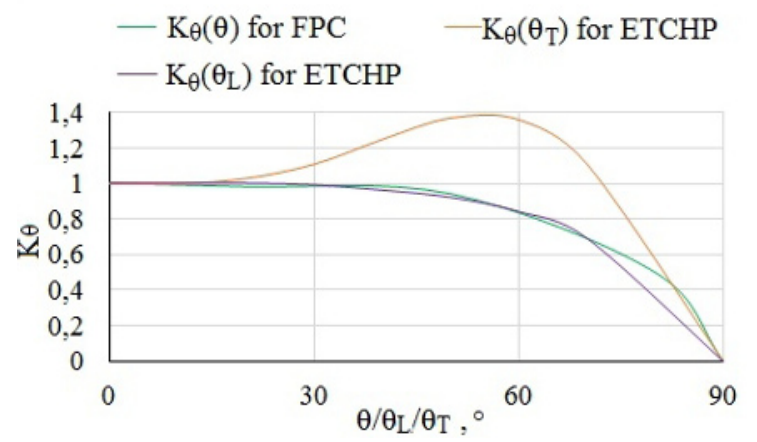

Figure 7. Incident angle modifiers for the FPC and ETCHP collectors included in the calculation model.

The available solar radiation incident for ETCHP was calculated with the following formula:

$$
\begin{aligned}
& G(\tau)=R_{b}(\tau) \cdot K_{\theta}(\tau) \cdot\left(G_{d}(\tau)+A i(\tau) \cdot G_{s d}(\tau)\right)+R_{d} . \\
& \pi \cdot F_{c s} \cdot K_{\theta d} \cdot(1-A i(\tau)) \cdot\left(1+R_{j h}(\tau)\right)+w_{o} \cdot R_{o} \cdot \pi
\end{aligned}
$$




$$
\begin{gathered}
F_{c s} \cdot K_{\theta d} \cdot\left(G_{d}(\tau)+G_{s d}(\tau)\right)+r_{c} \cdot R_{o t} \cdot \pi \cdot F_{c s} \cdot K_{\theta d} \\
\left(G_{d}(\tau)+G_{s d}(\tau)\right)
\end{gathered}
$$

$\mathrm{F}_{\mathrm{cs}}$ - view factor from the collector front side to sky $r_{c}-$ reflectance of radiation by surfaces behind collector.

The view factor from the collector front side to the sky $\left(\mathrm{F}_{\mathrm{cs}}\right)$ associated with overlapping of the tubes, was determined on the basis of studies by Shah \& Furbo [19] and data provided by the Energosol [32]. For the analyzed ETCHP, the $F_{c s}$ is 0.3758 . Due to the circular shape of the absorber, the diffuse radiation it is not available for its entire circumference. The area available $\left(A_{d}\right)$ for the aforementioned radiation can be determined with the following equation:

$$
\mathrm{A}_{\mathrm{d}}=\pi \cdot \mathrm{F}_{\mathrm{cs}} \cdot \mathrm{d}_{\mathrm{a}} \cdot \mathrm{L} \cdot \mathrm{p}
$$

where:

$\mathrm{d}_{\mathrm{a}}-$ diameter of absorber, $\mathrm{m}$,

$\mathrm{p}$ - number of tubes,

$\mathrm{L}$ - length of tube, $\mathrm{m}$.

The paper assumes that the area available for the diffuse radiation is not dependent on the number of tubes and their geometrical parameters. In Equation 5 for the diffuse radiation were used values referenced to the absorber area $\left(\mathrm{AA}=1 \mathrm{~m}^{2}\right)$ according to the relation:

$$
\frac{A_{d}}{d_{a} \cdot \mathrm{L} \cdot \mathrm{p}}=\frac{A_{d}}{A A}=\pi \cdot F_{c S}
$$

For the diffuse radiation, referred to half of the tube circumference, a constant correction factor $\mathrm{K}_{\theta \mathrm{d}}$ equal 0.88 - different than for the beam radiation - has been determined. The access to radiation reflected by surfaces in front of the collector has been adjusted by the $F_{c s}$ factor [19]. Similarly, in the case of radiation reflected from the back, a $10 \%$ reflectance of radiation $\left(\mathrm{r}_{\mathrm{c}}\right)$ by surfaces behind the tubes has been taken into account. This value is affected by both the transmission of radiation between the tubes and the surfaces behind the collector.

ETCHP are characterized by different availability of solar radiation when compared to FPC. This is related to a different shape of absorber so that different parts of the absorber area receive various types of solar radiation. Major importance for ETCHP is also passive solar tracking. In the case of ETCHP, the correction factors $\left(\mathrm{K}_{\theta}\right)$ are considered in relation to the two angles: longitudinal incidence angle $\left(\theta_{\mathrm{L}}\right)$ and transversal incidence angle $\left(\theta_{T}\right)$. Values of the angles for each hour of the reference year were determined according to formula from the EMD company guide [42]. The correction factor associated with transversal angle $\left(\mathrm{K}_{\theta}\left(\theta_{\mathrm{T}}\right)\right)$, related to the tilt of tubes, depends on the distances between the axes of tubes $\left(\mathrm{d}_{\mathrm{bp}}\right)$ and the diameter of the absorber $\left(\mathrm{d}_{\mathrm{ap}}\right)$. On the basis of the data from Energosol company [32], a polynomial approximation of the correction factors $\left(\mathrm{K}_{\theta}\right)$ for both types of angles $\left(\theta_{\mathrm{L}}, \theta_{\mathrm{T}}\right)$ has been determined (Fig.7). The correction factor $\mathrm{K}_{\theta}(\tau)$, used in eqn. 5, was established with the following equation $[44,45]$ :

$$
\mathrm{K}_{\theta}(\tau)=\mathrm{K}_{\theta}\left(\theta_{\mathrm{T}}(\tau)\right) \cdot \mathrm{K}_{\theta}\left(\theta_{\mathrm{L}}(\tau)\right)
$$

The correction factor in relation to longitudinal angle $\left(\mathrm{K}_{\theta}\left(\theta_{\mathrm{L}}\right)\right)$ is dependent on the difference between the tilt angle $(\beta)$ and the angle of solar altitude above the horizon. Due to the achieved value of the $\theta_{\mathrm{L}}$ angle (no larger than $60^{\circ}$ ) for $\beta=30^{\circ}$, the discussed correction factor is irrelevant for the calculations.

The monthly total insolation available for $1 \mathrm{~m}^{2}$ of the absorber area and the gross area for both collectors was calculated according to the relationship (4) or (5) and (8) is presented in Fig. 8.

$$
I(\text { month })=\sum_{\tau 1}^{\tau n} G(\tau) \cdot \frac{1 h}{1000}
$$

where:

$\mathrm{I}$ - insolation, $\mathrm{kWh} / \mathrm{m}^{2}$

$\tau 1$ - first hour of a month, $\tau$ n- last hour of a month.

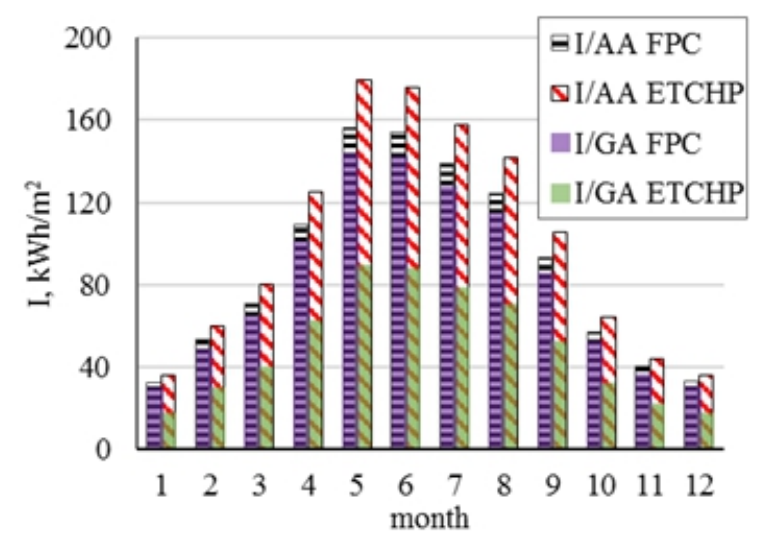

Figure 8. The comparison of available monthly insolation (I) for flat plate collectors (FPC) and evacuated tube collectors with heat pipe (ETCHP) calculated for the absorber area (AA) and the gross area (GA).

Generally, the available solar radiation incident values (G) determined from the data from the reference year (Equation 4,5 ) are used to indicate the solar yield (Q):

$$
\mathrm{Q}=\mathrm{AA} \cdot \mathrm{G} \cdot \eta
$$

where:

$\eta$ - efficiency of the collectors depending on time and demand.

Thus, $\mathrm{G}$ value is determined on the basis of the average solar radiation from 30 years. In fact, solar yields for each month in subsequent years can significantly differ from the average values, which can result in oversized or undersized area of the collector.

In this paper, based on the known average solar radiation from 30 years (from the reference year) and the known standard deviations from 126 years of solar radiation measurements in Cracow (Table 3) [46], a model of standard deviations of solar yields has been created. The monthly insolation values for a period of 100 years have been determined using the Monte Carlo method. The values obtained allowed calculating the correction factor $(\sigma)$ for the intensity of radiation taken into consideration when determining the average value of solar yields. A constant value from the reference year, usually assumed in the calculations, and the insulation values 
obtained using the Monte Carlo method for the month of July, is presented in Fig. 9.

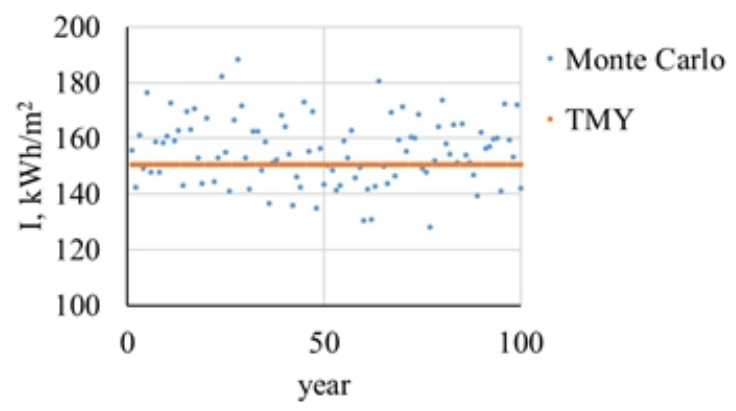

Figure 9. The comparison of values from Monte Carlo method with the values from the reference year (TMY - typical meteorological year) for July.

Table 3. TMY insolation and standard deviation percentage values $[13,46]$.

\begin{tabular}{|l|c|c|}
\hline Month & $\begin{array}{c}\text { Insolation, } \\
\mathbf{k W h} / \mathbf{m}^{\mathbf{2}}\end{array}$ & $\begin{array}{c}\text { Standard de viation, } \\
\mathbf{\%}\end{array}$ \\
\hline January & 26 & 7.6 \\
\hline February & 43 & 9.1 \\
\hline March & 66 & 8.4 \\
\hline April & 106 & 8.4 \\
\hline May & 163 & 7.7 \\
\hline June & 167 & 7.8 \\
\hline July & 151 & 7.3 \\
\hline August & 126 & 6.5 \\
\hline September & 90 & 8.8 \\
\hline October & 52 & 8.5 \\
\hline November & 32 & 6.9 \\
\hline December & 24 & 6.9 \\
\hline
\end{tabular}

\section{The calculation of solar yields}

The amount of energy obtained (Q1h) for $1 \mathrm{~m}^{2}$ of the absorber area (AA) over $1 \mathrm{~h}$ has been determined according to the relationship (11). The value has been determined for each hour of the year for a period of 100 years.

$$
\mathrm{Q} 1 \mathrm{~h}(\tau, \mathrm{y}, \mathrm{m})=\mathrm{AA} \cdot \mathrm{G}(\tau, \mathrm{y}, \mathrm{m})^{\prime} \cdot \eta^{\mathrm{i}}\left(\tau, \mathrm{T}_{\mathrm{m}}\right) \cdot 1 \mathrm{~h}
$$

where:

$\eta^{\mathrm{i}}\left(\tau, \mathrm{r}, \mathrm{m}, \mathrm{T}_{\mathrm{m}}\right)$ - efficiency of the collectors depending on time and demand,

$\tau$ - hour of reference year,

$\mathrm{y}$ - calculation year,

$\mathrm{m}-$ month of reference year.

The intensity of all types of solar radiation (Fig. 6) available at a given time has been calculated using the HDKR model (4 and 5) and then modified by taking into account the estimates for a period of 100 years:

$$
\mathrm{G}(\tau, \mathrm{y}, \mathrm{m})^{\prime}=\mathrm{G}(\tau) \cdot \sigma(\mathrm{y}, \mathrm{m})
$$

where:

$\mathrm{G}(\tau)$-available intensity of solar radiation incident on absorber dependent on time (for the average year), $\mathrm{W} / \mathrm{m}^{2}$, $\sigma(\mathrm{y}, \mathrm{m})-$ correction factor for the intensity of radiation in the subsequent calculation years (y) and months (m) determined using the Monte Carlo method.

In the case of solar systems, the temperature difference of the fluid at the inlet and outlet of the collector $\left(\mathrm{T}_{\mathrm{m}}\right)$ depends on the degree of meeting the heat demand $\left(\operatorname{shd}_{\mathrm{m}}\right)$. The average monthly value of $\mathrm{T}_{\mathrm{m}}$ is determined by iteration. Due to the actual operating temperature of the solar system it is assumed that the monthly average temperature of the fluid is in the range from $T_{\min }=20^{\circ} \mathrm{C}$ to $\mathrm{T}_{\max }=50^{\circ} \mathrm{C}[33]$. The efficiency of heat transfer from the collectors to the solar tank $\left(\eta_{\mathrm{ts}}\right)$ was $90 \%$. The subsequent $\mathrm{T}_{\mathrm{m}}$ values are calculated with the equation (12). It has been assumed that the monthly heat demand for domestic hot water $\left(\mathrm{Q}_{\mathrm{w}, \mathrm{m}}\right)$ is equal to $1 / 12$ of the annual demand $\left(\mathrm{Q}_{\mathrm{w}, \mathrm{a}}\right)$ from eqn. (1).

$$
T_{m}^{i}(y)=\frac{Q_{m}^{i}(y) \cdot \eta_{t s}}{Q_{W, m}} \cdot\left(T_{\max }-T_{\min }\right)+T_{\min }
$$

where:

$Q_{m}^{i}(y)$ - calculated theoretical monthly solar yields for a given calculation year, $\mathrm{kWh}$,

$\mathrm{QW}_{\mathrm{w}, \mathrm{m}}$ - monthly heat demand for DHW, kWh,

$\eta_{\mathrm{ts}}$ - efficiency of heat transfer from collectors to solar tank,

$\mathrm{y}$ - calculation year.

Theoretical monthly solar yields for a given calculation year have been determined according to the relationship:

$$
Q_{m}^{i}(y)=\sum_{\tau 1}^{\tau n} Q 1 h(\tau, y, m)
$$

For the available insolation shown in Fig. 9, adjusted for subsequent calculation years and determined according to the algorithm (12) $\mathrm{T}_{\mathrm{m}}$, the theoretical efficiency of collectors has been determined [47]:

$$
\begin{gathered}
\eta^{i}(\tau, y, m, T m)=\eta_{0}-a 1 \cdot \frac{T_{m}^{i}-T a(\tau)}{G(\tau, y, m) \prime}-a 2 \cdot G(\tau, y, m)^{\prime} . \\
\left(\frac{T_{m}^{i}-T a(\tau)}{G(\tau, y, m) \prime}\right)^{2}
\end{gathered}
$$

where:

$\eta$ - efficiency of the collectors depending on time and demand,

$\eta_{\mathrm{o}}-$ optical efficiency of collector,

$\mathrm{a}_{1}$ - linear heat loss coefficient, $\mathrm{W} /\left(\mathrm{m}^{2} \cdot \mathrm{K}\right)$,

$\mathrm{a}_{2}$-nonlinear heat loss coefficient, $\mathrm{W} /\left(\mathrm{m}^{2} \cdot \mathrm{K}^{2}\right)$,

$\mathrm{T}_{\mathrm{m}}-$ average temperature between inlet and outlet of collector, ${ }^{\circ} \mathrm{C}$,

$\mathrm{T}_{\mathrm{a}}-$ ambient temperature, ${ }^{\circ} \mathrm{C}$,

$\mathrm{G}(\tau, \mathrm{y}, \mathrm{m})$ '-available, corrected intensity of solar radiation incident on the absorber, $\mathrm{W} / \mathrm{m}^{2}$.

For the calculated annual heat demand eqn. (1) ranging from 1000 to $10000 \mathrm{kWh} /$ year, the annual solar energy $\left(\mathrm{Q}_{\mathrm{y}}\right)$ has been determined according to the eqn. (16). The simulation result is shown in Fig. 10.

$$
Q_{y}=\sum_{I}^{X I I} \frac{\sum_{y=1}^{100} Q_{m}(y)}{100}
$$




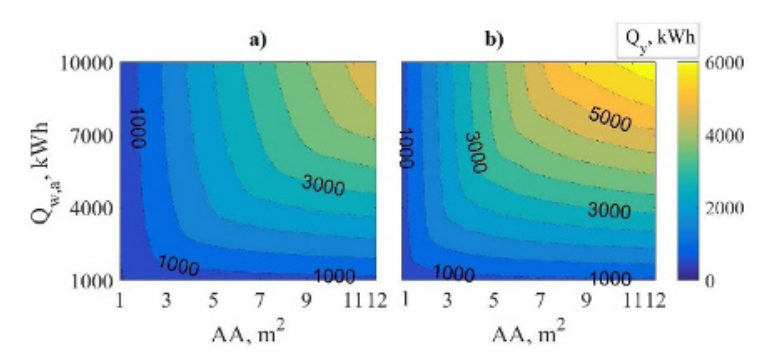

Figure 10. The theoretical solar yields $\left(Q_{y}\right)$ for: a) FPC, b) ETCHP as a function of the absorber area (AA) and heat demand of the installation $\left(\mathrm{Q}_{\mathrm{w}, \mathrm{a}}\right)$.

The monthly degree of meeting the heat demand for domestic hot water $\left(\operatorname{shd}_{\mathrm{m}}\right)$ is determined as the ratio of solar yields $\left(\mathrm{Q}_{\mathrm{m})}\right.$ to the heat demand $\left(\mathrm{Q}_{\mathrm{w}, \mathrm{m}}\right)$. The values of solar yields determined on the basis of relationship (14) for a period of 100 years have been averaged.

$$
s h d_{m}=\frac{\sum_{y=1}^{100} Q_{m}(y)}{100 \cdot Q_{W, m}}
$$

where:

$\mathrm{Q}_{\mathrm{m}}(\mathrm{y})$ - calculated monthly solar yields for a given calculation year according to eqn. (14),

$\mathrm{y}$ - The calculation year (from a period of 100 simulated years).

The average share in annual heat demand for domestic hot water provided by solar collectors:

$$
\text { shd }=\frac{\sum_{\mathrm{I}}^{\mathrm{XII}} \operatorname{shd}_{\mathrm{m}}}{12}
$$

where:

shd - average share in meeting the annual heat demand calculated in months from I (January) to XII (December).

The share in annual heat demand, depending on the absorber, gross and aperture area, is presented in Figure 11-15.

Knowing the number of residents of a single-family house and the amount of used hot water, the heat demand for DHW can be determined according to the eqn (1). The aforementioned heat demand for a given building can also be determined on the basis of the energy performance of building. With the known heat demand and degree of meeting the demand (ranging from 0 to $90 \%$ ), it is possible to determine the required collectors area on the basis of nomograms presented in Figures 11-15. For example, the annual heat demand for DHW for an average family of 4 persons, $40 \mathrm{dm}^{3}$ per person per day, is $4800 \mathrm{kWh} /$ year. The absorber areas of both types of the analyzed collectors, determined on the basis of Figures 11 and 14 and depending on the degree of meeting the heat demand, are shown in Figure 16.

Despite significantly lower access to sunlight calculated on the gross area of ETCHP, meeting $40 \%$ of the demand requires minimally larger surface when compared to FPC. An inverse relationship occurs in the case of coverage of $60 \%$ of the heat demand per year. Increasing the demand coverage from $40 \%$ to $60 \%$ for both types of collectors requires to double area of the absorber. In this case, especially in the summer, the yields are excessive compared to the needs. The excess energy can

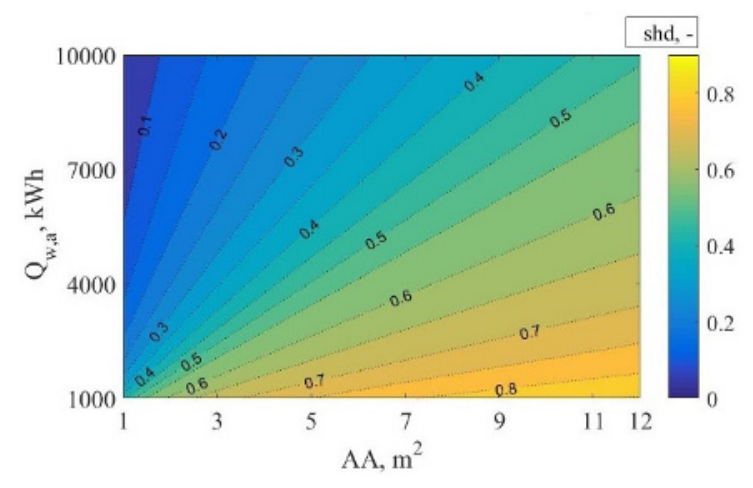

Figure 11. The share in meeting the annual heat demand (shd) for flat plate collectors as a function of the absorber area (AA) and heat demand $\left(\mathrm{Q}_{\mathrm{w}, \mathrm{a}}\right)$.

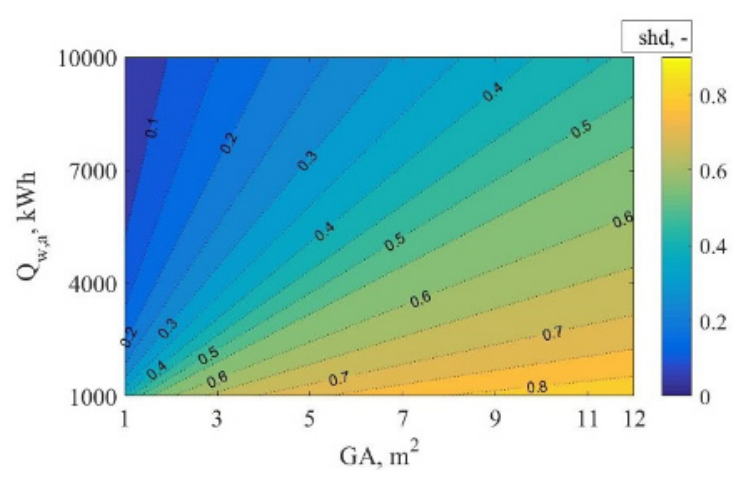

Figure 12. The share in meeting the annual heat demand (shd) for flat plate collectors as a function of the gross area of the collector $(\mathrm{GA})$ and heat demand $\left(\mathrm{Q}_{\mathrm{w}, \mathrm{a}}\right)$.

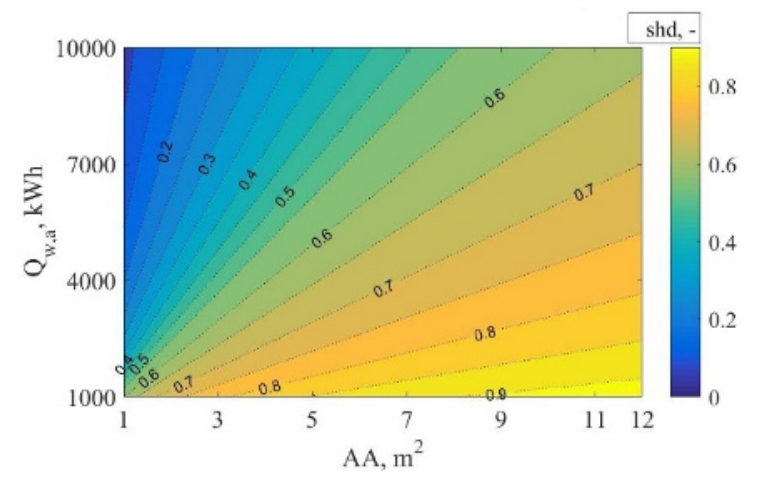

Figure 13. The share in meeting the annual heat demand (shd) for ETCHP as a function of the absorber area (AA) and heat demand $\left(\mathrm{Q}_{\mathrm{w}, \mathrm{a}}\right)$.

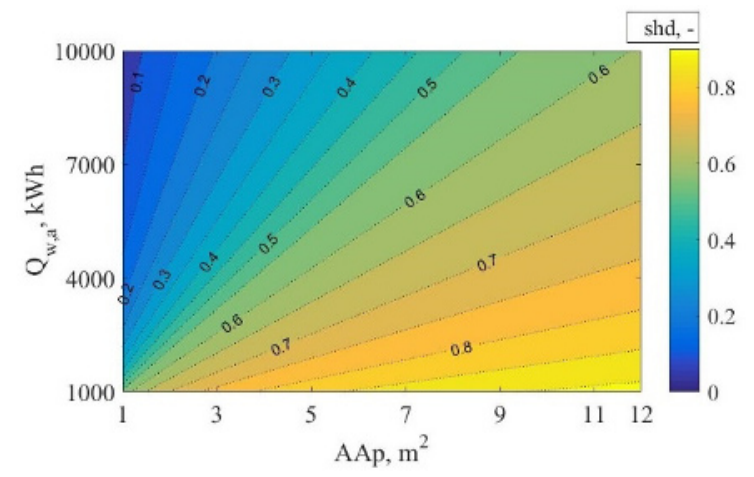

Figure 14. The share in meeting the annual heat demand (shd) for evacuated tube collectors with heat pipe as a function of the aperture area (AAp) and heat demand $\left(\mathrm{Q}_{\mathrm{w}, \mathrm{a}}\right)$. 


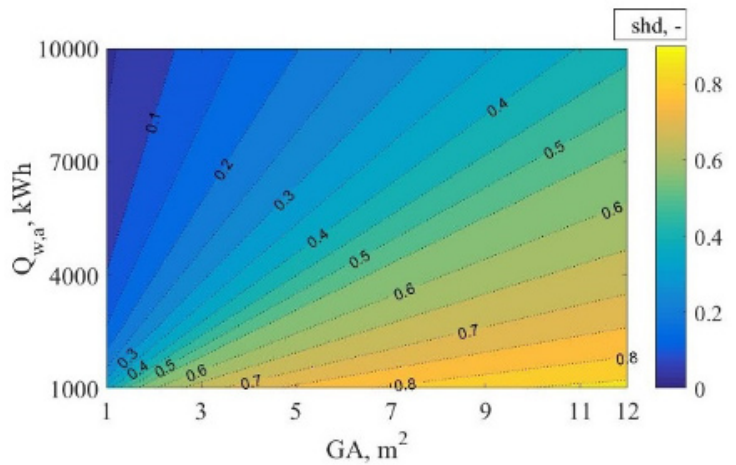

Figure 15. The share in meeting the annual heat demand (shd) for ETCHP as a function of the gross area of the collector (GA) and heat demand $\left(\mathrm{Q}_{\mathrm{w}, \mathrm{a}}\right)$

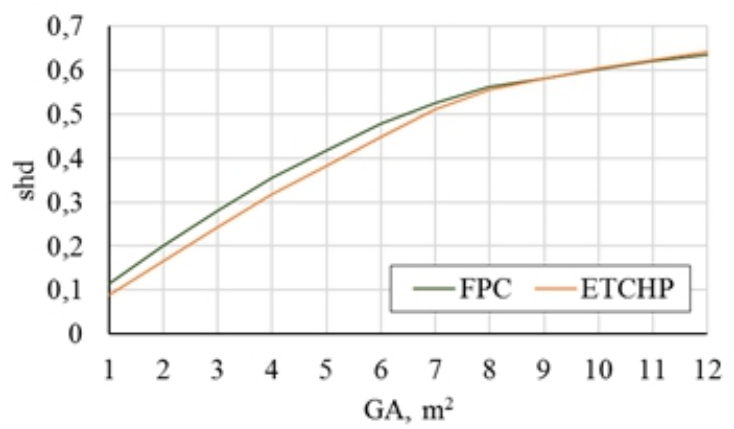

Figure 16. The summary results for heat demand, $\mathrm{Q}_{\mathrm{w}, \mathrm{a}}=4800$ $\mathrm{kWh} /$ year; shd - the share in meeting the annual heat demand, $\mathrm{GA}$ - the gross area of the collector

not be stored more than a few days without the use of additional technologies.

The degree of utilization of solar collectors was determined on the basis of the useful efficiency, calculated according to the relationship (19):

$$
U E=\frac{Q_{y}}{I \cdot A A}
$$

where:

UE - useful efficiency.

The useful efficiency of solar collectors as a function of the absorber area and heat demand is shown in Figure 17 .

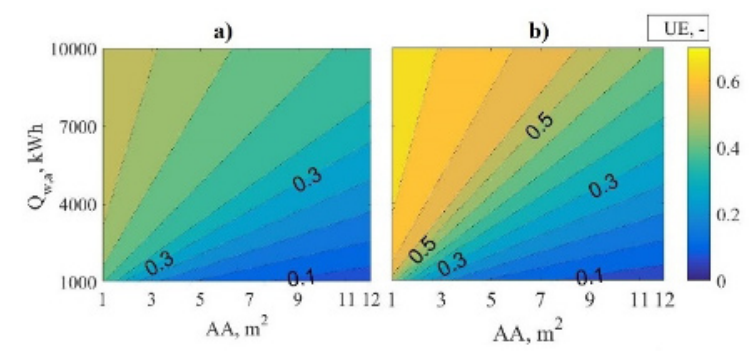

Figure 17. The useful efficiency of: a) FPC, b) ETCHP as a function of the absorber surface and heat demand.

For both types of collectors most useful efficiency $(>50 \%)$ is obtained for small absorber area and a high heat demand. Due to the higher efficiency and better access to insolation (Figure 8.) ETCHP have greater useful efficiency regardless of heat demand and surface change.
The useful efficiency preseented in Figure 17 is affected, among others, by the average temperature of the absorber $\left(\mathrm{T}_{\mathrm{m}}\right)$, depending on the coverage of heat demand on a monthly basis and the amount of unused energy, mainly in the summer months. In addition, exploiting the potential of the devices, and thus the costs, are of crucial importance. However, this is an optimization issue separated from the demand coverage and useful efficiency of solar energy generation.

\section{Summary}

Due to the variability in solar radiation over a year and the changing weather conditions, it is difficult to ensure a high level of coverage of the heat demand. By increasing the absorber area, it is possible to increase the share in heat demand coverage in the months of spring and summer. Further increasing of the absorber surface increases the possibility to cover the heat demand in the winter months.

Due to the lower heat loss rates, the use of ETCHP is more favorable in the annual balance sheet. The shares in meeting the heat demand suggest non-linear relationship between the coverage of heat demand and the analyzed surfaces. This is related to, among others, adverse working conditions of collectors in the winter months and surpluses, gained during the summer, which cannot be used. Therefore, the ongoing efforts to increase the share result in a low efficiency.

\section{References}

1. K. Neupauer, J. Magiera, Technical Transactions, 4, 57 (2009) (in polish)

2. IEO for Mazowiecka Energy Agency, Available: http://www.mae.com.pl/files/poradnik-dlauzytkownikow-instalacji-slonecznych-namazowszu_-mae.pdf, ( 0704 2016) (in polish)

3. GeoModel Solar, Available: http://solargis.info/doc/_pics/freemaps/1000px/ghi/S olarGIS-Solar-map-Europe-en.png, (22 12 2015)

4. A. Głuszek, J. Magiera, Polityka energetyczna, 11, 41-19 (2008), (in polish)

5. A. Więcka, Available: http://www.terazsrodowisko.pl/aktualnosci/Zapomniane-kolektorysloneczne-829.html, (07 04 2016), (in polish)

6. GUS, „Energia ze źródeł odnawialnych w 2014 r.” (GUS, Warszawa, 2015), (in polish)

7. D. Kryzia, P. Olczak, Logistyka, 4, 4587 (2014), (in polish).

8. K. Żarski, Civil and Environmental Engineering, 59, 905 (2012), (in polish)

9. K. Kurowski, Instal Reporter, 17, 14 (2011), (in polish)

10. M. Żukowski, P. Radzajewska, District Heating, Heating,Ventilation, 46, 138-142 (2015), (in polish)

11. J. Dziedzic, P. Olczak, D. Kryzia, Logistyka, 4, 88328840 (2015), (in polish)

12. K. Pytel, A. Kłos, Civil and Environmental Engineering, 59, 650 (2012), (in polish).

13. Minister Infrastruktury i Rozwoju, Dz.U. 2015,376, (2015), (in polish)

14. M. Kwietniewski, K. Miszta-Kruk, A. Piotrowska, Technical Transations Environmental Engineering, 108, 113-127 (2011), (in polish) 
15. Minister Infrastruktury i Rozwoju, Dz.U. 2015, 1422, (2015), (in polish)

16. P. Bugajski, Infrastructure and Ecology of Rural Areas, 105-1132 (2009), (in polish)

17. P. Bugajski, G. Kaczor, Infrastructure and Ecology of Rural Areas, 17-26 (2005), (in polish)

18. EuroObservER,Available: http://www.energiesrenouvelables.org/observer/stat_baro/observ/baro215.pdf. (07 04 2016)

19. L. Shāh, S. Furbo, Applied Energy, 78, 374-378 (2004)

20. L. Fen Su, L. Miao, S. Tanemura, G. Xu, Science and Technology of Advanced Materials, 13, 4 (2012)

21. ET Polska, Available: http://www.etpolska.com/pl/oferta/kolektoryplaskie.html. (22 12 2015)

22. Hewalex, Available: http://www.hewalex.pl/oferta/plaskie-kolektorysloneczne/kolektor-sloneczny-ks2000-tp-am.html. (22 12 2015)

23. Sonneko, Available: http://sonneko.pl/dat/attach/449_kolektor_plaski.pdf. (21 12 2015), (in polish)

24. Veelman, http://www.veelman.com/pl/produkty/kolektorysolarne-plaskie (21 12 2015), (in polish)

25. Watt, http://www.watt.pl/pl/produkty/kolektorysloneczne/kolektory-plaskie/watt-2020-s.html. (21 12 2015), (in polish)

26. Watt, http://www.watt.pl/pl/produkty/kolektoryAvailable: sloneczne/kolektory-plaskie/watt-3020-s.html. (21 12 2015), (in polish)

27. Watt, http://www.watt.pl/pl/produkty/kolektorysloneczne/kolektory-plaskie/kolektor-slonecznywatt-8020.html (21 12 2015), (in polish)

28. Watt sp. z o.o., Watt CPC 9+ (ISFH, Emmerthal, 2012), (in polish)

29. Ensol, http://www.ensol.pl/solartermia/kolektorysloneczne/plaskie/z-absorberem-meandrycznymaluminiowym/es2v20sal.html. (22 12 2015), (in polish)

30. Biawar, Available: http://www.biawar.com.pl/systemy-solarne/heveliuswunder-kolektory-plaskie/hevelius-cls-3-bz. (02 01 2016), (in polish)

31. K. Neupauer, J. Magiera, Technical Transactions, 10, 223-232 (2010), (in polish)

32. ENERGOSOL, Available: http://www.energosol.pl/oferta_kolektory_sloneczne kolektory_prozniowe.html.(29 082015$)$, (in polish)

33. $\overline{\mathrm{P}}$. Olczak, J. Zabagło, District Heating, Heating,Ventilation, 46, 430 (2015), (in polish)

34. S. Kandefer i P. Olczak, District Heating, Heating,Ventilation, 46, 11-13 (2015), (in polish).

35. Watt sp. $z \quad$ o. o., Available: http://www.watt.pl/pl/imagesdb_a0ff1 f78dcaab2cb7b 4b70db2a649c3a.pdf. (20 03 2016), (in polish)
36. D. Chwieduk, Modelowanie i analiza pozyskiwania oraz konwersji termicznej energii promieniowania słonecznego wbudynku (Warszawa IPPT PAN, 2006), (in polish)

37. P. Olczak, J. Zabagło, S. Kandefer i J. Dziedzic, Między ewolucją a rewolucją - w poszukiwaniu strategii energetycznej, II, 739-752 (2015), (in polish)

38. OGIMET

Available: http://ogimet.com/resynops.phtml.en. (10 11 2015)

39. J. A. Duffie i W. Beckman, Solar Engineering of Thermal Processes, 2006.

40. J. Karlsson, Windows - Optical Performance and Energy Efficiency (Uppsala, 2001)

41. P. Loutzenhiser, H. Manz, C. Felsmann, P. Strachan, G. Maxwell, Solar Energy, 81, 254-267 (2007)

42. Ministerstwo Infrastruktury i Rozwoju, Available: http://www.mir.gov.pl/strony/zadania/budownictwo/ dane-do-swiadectw-charakterystyki-energetycznejbudynkow (23 07 2015), (in polish)

43. J. Zimny, R. Brzegowy, S. Bielik, Kolektory słoneczne (Kraków 2013), (in polish)

44. J. P. Ryan, Incidence angle modifiers in cylindrical solar collector design (Fort Collins 1997)

45. EMD International $\mathrm{A} / \mathrm{S}$, Solar Collectors and Photovoltaic, Available: http://www.emd.dk/files/energypro/Solar\%20Collect or $\% 20$ and $\% 20$ Photovoltaic $\% 20$ in $\% 20$ energyPRO.pd f(10 11 2015)

46. D. Matuszko, International Journal of Climatology, 34, 228-234 (2014)

47. M. Rodríguez-Hidalgo, P. Rodríguez-Aumente, A. Lecuona, G. Gutiérrez-Urueta, R. Ventas, Applied Thermal Engineering, 31, 2385 (2011) 